\title{
Formal reporting style (Journalistic Reporting Styles)
}

\section{AUTHOR}

Miriam Steiner

\section{KEYWORDS}

genre, news format, news story, newspaper, TV, radio, online

\section{BRIEF DESCRIPTION}

Formal reporting styles refer to news formats or journalistic genres within a media outlet, e.g., news stories as the standard formal reporting style but also interviews as an alternative form of journalistic coverage. Each formal reporting style or news format is associated with specific rules of how to write it. For example, the journalist has to answer the most important W-questions (Who, What, When, Where, Why) at the beginning of a news story whereas feature journalism builds up tension, that is, tells a story and the important questions are answered only in the course of the article. The interview as another example is characterized by the formal interplay between questions (interviewer) and answers (interviewee). Apart from general reporting styles (news story, interview etc.), some codebooks also measure media-specific reporting styles (e.g., Donsbach \& Büttner, 2005 for television). Furthermore, reporting styles can be distinguished between "rather factual" or "rather opinionated" (Seethaler, 2015).

\section{FIELD OF APPLICATION/THEORETICAL FOUNDATION}

Formal reporting styles can be seen as a formal variable of quantitative content analyses which is therefore often part of the "standard repertoire" within codebooks that analyse journalistic (news) coverage. It can be used to identify different news formats (e.g., the share of comments in quality newspapers). It can also be used for research conducted on the norm of separating news and opinion. It may also be helpful in determining the units of analysis within analyses of news coverage. For example, if a news story is followed by an interview with a politician on the same issue, this change in the formal reporting style often means a new unit of analysis in content analyses.

\section{REFERENCES/COMBINATION WITH OTHER METHODS OF DATA COLLECTION}

Content analyses can also be combined with surveys or qualitative interviews. One example is a study by Schäfer-Hock (2018), in which he examined how journalistic reporting has changed within recent years. In order to gain more in-depth insights into this, he combined the findings of a quantitative content analysis (years 1992 and 2012) with guided interviews conducted with journalists from the analysed newspapers.

\section{EXAMPLE STUDIES}

Donsbach \& Büttner (2005); Kösters (2020); Seethaler (2015)

\section{INFORMATION ON KÖSTERS, 2020}

Author: Raphael Kösters

This study is part of the DFG-project "Media Performance and Democracy" (https://en.mediaperformance.uni-mainz.de/)

Research question: The project investigates how media interpret political topics with regard to political value orientations (value framing) by means of a standardized content analysis. The study aims to answer the question whether the political heterogeneity of modern societies is reflected in media reporting. The analysis is conducted on news coverage about migration. 
Object of analysis: The study investigates news coverage on the issue "migration" in German news media: 1) newspapers/ news magazines (Frankfurter Allgemeine Zeitung, Süddeutsche Zeitung, ZEIT, SPIEGEL, BILD, Rheinische Post, taz, Junge Freiheit, junge Welt); 2) TV (Tagesschau, RTL Aktuell), 3) radio (WDR Aktuell - Der Tag); 4) online (t-online.de, bild.de, spiegel.de, faz.net, tagesschau.de, sueddeutsche.de)

Time frame of analysis: March 1, 2018 to July 6, 2018

\section{INFO ABOUT THE VARIABLE}

Variable name: Stilform [reporting style]

Level of analysis: article

Values (in German): 1) Nachricht, Bericht; 2) Reportage, Feature, Portraits; 3) Kommentar, Kolumne, Glosse, Leitartikel; 4) Interview; 8) sonstiges

Level of measurement: nominal

Reliability: five student coders, Holsti: 0.93

Codebook: attached (in German)

\section{INFORMATION ON SEETHALER, 2015}

Author: Josef Seethaler

Research question: The study is a cross-media analysis of media performance in Austria. Furthermore, media performance indicators are evaluated from the standpoint of different models of democracy (representative liberal, deliberative, participatory).

Object of analysis: 1) newspapers (paid press: Standard, Presse, Kleine Zeitung, Kronen Zeitung, Kurier, Oberösterreichische Nachrichten, Salzburger Nachrichten, Tiroler Tageszeitung, Vorarlberger Nachrichten); 2) newspapers (free dailies: Heute, Österreich); 3) public service/ commercial and national/regional radio stations (Ö1, Ö3, FM4, KRONEHIT, ORF - Radio Niederösterreich, Radio Oberösterreich, Radio Steiermark, Radio Wien, 88.6 Wien, Antenne Steiermark, Life Radio Oberösterreich, Radio Arabella Wien, Radio Energy Wien); 4) national public service (ORF eins, ORF 2, ORF III) and commercial (ATV I, ATV II, PULS 4, ServusTV) TV stations; 5) online (derstandard.at, krone.at, oe24.at, orf.at, gmx.at)

Time frame of analysis: four artificial weeks (without Sundays) in 2014

In this study, the codebook does not distinguish different news formats/ formal reporting styles, but generally differentiates between factual-based and opinion-based reporting styles (as well as interviews that cannot be categorized properly).

\section{INFO ABOUT THE VARIABLE}

Variable name: Journalistische Stilform [journalistic reporting style]

Level of analysis: article

Values (in German): 1) tatsachenbetont: (Nachricht, Bericht, Reportage, Feature, Personenporträt, Dokumentation, in der Zeitung: auch Foto als Einzelbild); 2) meinungsbetont: Kommentar, [Print/Online:] Leitartikel, Glosse, Karikatur; 3 Interviews, Talks; 9) nicht entscheidbar

Level of measurement: nominal

Reliability: six coders, Fleiss' Kappa: 0.90

Codebook (in German) available under: https:// www.rtr.at/medien/aktuelles/publikationen/Publikationen/SchriftenreiheNr12015.de.html

INFORMATION ON DONSBACH \& BÜTTNER, 2005

Authors: Wolfgang Donsbach, Katrin Büttner

Research question: The study examines the presentation of political news coverage in the most important public service and commercial main German newscasts in 1983, 1990 and 1998 with the aim of revealing changes in the presentation of politics and the extent to which there are convergent trends ( $\rightarrow$ tabloidization).

object of analysis: news on politics within four German newscasts: Tagesschau (ARD), ZDF heute, Sat.1 Blick/18.30, RTL Aktuell (in 1983: only Tagesschau and ZDF heute)

Time frame of analysis: for each year, every second day within the last four weeks before election day were analysed: 1) February 7, 1983 to March 6, 1983 (March 6, 1983 = election day); 2) November 5, 1990 to December 2, 1990 (December 2, 1990 = election day); 3) August 31, 1998 to September 27, 1998 (September 27, 1998 = election day)

\section{INFO ABOUT THE VARIABLE}

This variable measures TV-specific formats but also includes general journalistic formats.

Variable name: Darstellungsformen [forms of presentation]

Level of analysis: news report

Values (in German): 1) Anmoderation; 2) Ab- bzw. Zwischenmoderation; 3) Meldung; 4) Nachrichtenfilm; 5) Bericht; 6) Interview; 7) Statement/ 
Redeausschnitt; 8) Kommentar; 9) sonstige Präsentationsform

Level of measurement: nominal

Reliability: four coders, reliability: N.A.

Codebook (in German) available under: http:// donsbach.net/wp-content/uploads/2011/12/ Codebuch TV-Nachrichten.pdf

\section{REFERENCES}

Donsbach, W., \& Büttner, K. (2005). Boulevardisierungstrend in deutschen Fernsehnachrichten [Tabloidization trend in German TV news]. Publizistik, 50(1), 21-38.

Kösters, R. (2020). Medien als Mittler im Konflikt? Der Streit um die Migration im Spiegel der Berichterstattung [Media as intermediaries in conflicts? The debate on migration in media coverage]. (Doctoral dissertation, Heinrich-Heine-University Düsseldorf). Retrieved from https://d-nb.info/1203369883/34

Schäfer-Hock, C. (2018). Journalistische Darstellungsformen im Wandel. Eine Untersuchung deutscher Tageszeitungen von 1992 bis 2012 [Journalistic reporting styles in transition. A study of German daily newspapers from 1992 to 2012]. Wiesbaden: Springer

Seethaler, J. (2015). Qualität des tagesaktuellen Informationsangebots in den österreichischen Medien. Eine crossmediale Untersuchung [News media quality in Austria: A crossmedia analysis]. Rundfunk und Telekom Regulierungs-GmbH. Retrieved from https://www.rtr.at/de/inf/ SchriftenreiheNr12015/Band1-2015.pdf 